\title{
ANALISIS PENGARUH PENGGUNAAN CELEBRITY ENDORSER SYAHRINI TERHADAP MINAT BELI MIE SEDAP DI DAERAH ISTIMEWA YOGYAKARTA
}

\author{
Norman Miradi Indra Kurniawan \\ norman12011006@students.uad.ac.id \\ Universitas Ahmad Dahlan \\ Fitroh Adhilla \\ fita_uad@yahoo.com \\ Universitas Ahmad Dahlan
}

\begin{abstract}
ABSTRAK
This study aims to analyze the effect of television advertising on buying interest in savory noodle products that are influenced by endorsement with Syahrini as a celebrity endorser. In this study the population used was general consumers who had seen delicious noodles ads through television media in the Special Region of Yogyakarta. This research is a quantitative research. Data collection using a questionnaire method (questionnaire) that has been tested for validity using CFA (Confirmatory Factor Analysis) and reliability testing using Crobach Alpha, while data analysis is performed using multiple linear regression analysis. The subjects of this study were general consumers who had seen advertisements of delicious Mie products on television media, the sampling technique used purposive sampling and incidental sampling methods, the number of samples used was 80 respondents. The results showed that (1) there was a significant influence between credibility on the interest in buying delicious noodle products, (2) there was a significant effect on the compatibility of buying interest in delicious noodle products. (3) There is a significant influence between the attractiveness of buying interest in delicious noodle products. There is a positive and significant influence between credibility, compatibility and attractiveness together to the interest in buying delicious noodle products.
\end{abstract}

Keyword : Credibility; Compatibility; Attractiveness; Purchase Interest.

\begin{tabular}{l}
\hline PENDAHULUAN \\
${ } }$ \\
semakin tajam dalam memasuki era \\
globalisasi ini. Hal ini terlihat dengan \\
banyaknya persaingan yang timbul, setiap \\
perusahaan ingin menjadi yang terdepan \\
dibidangnya masing-masing atau minimal \\
mampu mempertahankan posisinya dalam \\
pasar bisnis Indonesia. Agar perusahaan \\
dapat bertahan dan berkembang dengan \\
kontinuitas yang semakin tinggi, \\
diperlukan pengelolaan usaha yang baik \\
salah satunya dengan pengoptimalan \\
strategi dalam pemasaran
\end{tabular}

Salah satu tahapan dalam pemasaran tersebut adalah periklanan. Periklanan adalah segala bentuk penyajian dan promosi ide, barang atau jasa secara non personal oleh suatu sponsor tertentu yang memerlukan pembayaran. Pilihan tujuan periklanan harus didasarkan pada analisis yang mendalam mengenai situasi pemasaran sekarang. Tujuan atau sasaran periklanan adalah suatu tugas komunikasi spesifik dan level keberhasilan yang harus dicapai atas audiens spesifik pada periode waktu yang spesifik. Tujuan periklanan harus dibuat operasional sehingga bisa diukur keberhasilannya.

Berbagai macam iklan produk yang banyak dan bervariasi membanjiri 
konsumen hadir melalui televisi, radio maupun media lainya. Media televisi lebih baik dalam mendemonstrasikan produk dibandingkan media cetak, media luar ruangan, dan lini bawah. Televisi mampu mengkomunikasikan suatu iklan dengan perincian suara, warna, dan gerakan yang lebih jelas untuk dipahami sehingga bisa memperlihatkan manfaat produk lebih realistis dibandingkan media lain. Hal ini didukung banyaknya penggunaan artis sebagai celebrity endorser menjadi salah satu strategi pemasaran, sangat efektif untuk membuat stoping power bagi audience.

Perusahaan makanan menyajikan tampilan-tampilan iklan produk makanan yang kreatif dan dengan brand endorser yang bervariasi serta ada juga yang memanfaatkan popularitas artis, hanya untuk mempengaruhi konsumen. Dalam hal ini konsumen diajak untuk berfantasi dan percaya bahwa dengan memakan produknya akan merasa lebih nikmat,kenyang,dan lain sebagainya.

Periklanan televisi digencarkan dengan kemunculan produk terbaru mie Sedap. Pada tahun 2016 Mie Sedap meluncurkan rasa barunya Rasa White Curry dengan Belasan Rempah yang Begitu Fenomenal Creamy. Rasa Kari Ayam bercampur Krimer adalah inovasi yang unik. Rasanya fenomenal creamy dan membuat lidah menari-nari kata Syahrini di iklan. Daya tarik Syahrini yang cantik dan menggemaskan membuat tampilan iklan lebih kreatif serta menarik

Kehadiran celebrity endorser yang sudah dipilih oleh perusahaan untuk produk mie sedap Rasa White Curry adalah sebagai ikon untuk mewakili perusahaan dan produk tersebut, karena perusahaan biasanya memilih tokoh-tokoh yang sedang digemari atau menjadi idola masyarakat karena prestasi maupun karena perilaku idola pada masing-masing bidang keahliannya.

Keberadaan selebriti dijadikan sebagai kekuatan untuk mempengaruhi dan menimbulkan minat atau tindakan yang berhubungan dengan pembelian atau penggunaan barang-barang atau jasa yang di iklankan selebriti tersebut terhadap masyarakat yang melihat iklan itu. Faktor kredibilitas selebriti semakin diragukan ketika seorang selebriti itu memiliki iklan yang banyak di beberapa merek produk. Perusahaan kurang memperhatikan tentang kredibilitas endorser yang dipilih, mereka hanya memanfaatkan popularitas, daya tarik, dan kondisi karir selebriti tersebut.

Menurut Shimp, (2003) bahwa dalam memilih selebriti pendukung untuk sebuah merek produk, ada beberapa hal yang harus diperhatikan, yaitu kredibilitas, kecocokan selebriti (dengan khayalak dan merek), daya tarik selebriti dan pertimbangan lainnya. Berdasarkan latar belakang tersebut, maka peneliti berusaha untuk mengetahui pengaruh celebrity endorser pada produk mie sedap terhadap minat beli. Oleh karena itu, penulis mengadakan penelitian dengan judul "Pengaruh Penggunaan Celebrity Endorser Syahrini Terhadap Minat Beli Mie Sedap di Daerah Istimewa Yogyakarta."

\section{Rumusan Masalah}

1. Apakah ada pengaruh kredibilitas celebrity endorser pada iklan mie sedap versi Syahrini terhadap minat beli mie sedap di Daerah Istimewa Yogyakarta?

2. Apakah ada pengaruh kecocokan celebrity endorser pada iklan mie sedap versi Syahrini terhadap minat beli mie sedap di Daerah Istimewa Yogyakarta?

3. Apakah ada pengaruh daya tarik celebrity endorser pada iklan mie sedap versi Syahrini terhadap minat beli mie sedap di Daerah Istimewa Yogyakarta?

4. Apakah ada pengaruh secara simultan/serempak celebrity endorser yang terdiri dari variabel kredibilitas, kecocokan, dan daya tarik mie sedap versi Syahrini terhadap minat beli mie sedap di Daerah Istimewa Yogyakarta? 


\section{REVIEW LITERATUR DAN HIPOTESIS}

\section{Landasan Teori}

\section{Celebrity Endorser}

Selebriti adalah tokoh (aktor, penghibur, atau atlet) yang dikenal masyarakat karena prestasinya di dalam bidang - bidang yang berbeda dari golongan produk yang didukung, (Shimp, 2003) Para selebriti banyak diminta sebagai juru bicara produk. Kemungkinan sebanyak $1 / 4$ dari semua iklan menggunakan dukungan selebriti.

Berikut dimensi-dimensi yang terdapat dalam celebrity endorser :

a. Kredibilitas Selebriti

Kredibilitas pendukung adalah keahlian dan kepercayaan (Shimp, 2003). Keahlian (expertise) mengacu pada pengetahuan, pengalaman, atau keterampilan yang dimiliki seorang pendukung yang berhubungan dengan topik iklannya. Kepercayaan (trustworthiness) mengacu pada kejujuran, integritas dan dapat dipercayai seorang sumber. Sementara keahlian dan kepercayaan tidak saling berhubungan timbal balik, sering kali seorang pendukung tertentu dianggap sangat dapat dipercaya padahal bukan orang yang ahli dibidang tersebut. Dapat dipercaya dan keahlian seorang selebriti merupakan alasan utama untuk memilih selebriti sebagai pendukung periklanan. Orang yang dapat dipercaya dan dianggap memiliki wawasan tentang isu tertentu, seperti kehendak merek, akan menjadi orang yang paling mampu meyakinkan orang lain untuk mengambil suatu tindakan.

b. Kecocokan Selebriti Dengan Khalayak dan Merek.
Kesamaan atau kecocokan ini merupakan atribut yang penting karena penonton cenderung lebih menyukai seseorang yang sedang berbagi dengan karakteristik yang sama (Shimp, 2003). Seorang selebriti yang yang sedang membintangi iklan produk tertentu sepertinya dianggap sosok yang terpecaya yang mempunyai kesamaan karakter dengan para penonton dalam hal gender, umur, etnis, dan kelas sosial. Para eksekutif menuntut agar citra selebriri, nilai, dan perilakunya sesuai dengan kesan yang diinginkan. Seorang pendukung yang menarik tidak akan memberikan manfaat bagi suatu produk bila kecocokannya kurang antara pendukung dan produk.

c. Daya Tarik Selebriti

Daya tarik bukan hanya berarti daya tarik fisik (Shimp, 2003). Meskipun daya tarik bisa menjadi atribut yang sangat penting, tetapi meliputi sejumlah karakteristik yang dapat dilihat khalayakdalam diri pendukung. Sifat-sifatkepribadian, gaya hidup, keatlisan postur tubuh dan sebagainya. Konsep umum dari daya tarik terdiri dari tiga ide yang berhubungan: persamaan (similarity), pengenalan (familiarity), dan penyukaan (liking). Yaitu, seorang seorang pendukung dianggap menarik oleh para khalayak bila mereka hanya menyukai si pendukung tanpa melihat apakah keduanya serupa di dalam segala hal. Dalam memilih selebriti sebagai pembicara, para eksekutif periklanan mengevaluasi aspek yang berbeda yang dapat disatukan di bawah sebutan umum daya tarik. Daya tarik meliputi keramahan, menyenangkan, fisik, dan pekerjaan sebagai beberapa dari dimensi penting dari konsep daya tarik. 


\section{Iklan}

Iklan merupakan salah satu komponen marketing mix yang umum dilakukan oleh perusahaan. Iklan juga merupakan setiap bentuk komunikasi yang dimaksudkan untuk memotivasi seseorang pembeli potensial dan mempromosikan penjual suatu produk atau jasa, untuk mempengaruhi pendapat publik, memenangkan dukungan publik untuk berpikir atau bertindak sesuai dengan keinginan si pemasang iklan. Selain itu, semua iklan dibuat dengan tujuan yang sama yaitu untuk memberi informasi dan membujuk para konsumen untuk mencoba atau mengikuti apa yang ada di iklan tersebut, dapat berupa aktivitas mengkonsumsi produk dan jasa yang ditawarkan.

Menurut Machfoedz (2010) bahwa iklan adalah segala bentuk penyajian informasi dan promosi secara tidak langsung yang dilakukan oleh sponsor untuk menawarkan ide, barang atau jasa.. Bentuk presentasi dan promosi non pribadi tentang ide, barang maupun jasa yang dibayar oleh sponsor untuk memberikan informasi kepada masyarakat. Dalam kehidupan masyarakat yang sudah maju dan kompleks, iklan berevolusi ke dalam sistem komunikasi vital masyarakat, terutama dunia bisnis. Beriklan perlu metode promosi yang seakurat mungkin karena imbasnya sedemikian dahsyat kepada khalayak, baik dalam hal isi pesan maupun penyampaian.

\section{Minat Beli}

Minat beli konsumen adalah inisiatif responden dalam pengambilan keputusan untuk membeli sebuah produk. Model terperinci perilaku konsumen tersebut menjelaskan bahwa rangsangan pemasaran yang terdiri dari variable marketing mix yaitu produk, harga, tempat, promosi sebagai komponen utama dalam pemasaran. Komponen utama tersebut juga dipengaruhi oleh adanya rangsangan lainnya yaitu bersifat eksternal yaitu ekonomi, teknologi, politik, budaya, (Oentoro, 2012).

\section{Penelitian Terdahulu}

Abdur Rofiq, (2016) melakukan penelitian dengan judul. "PENGARUH PENGGUNAAN CELEBRITY ENDORSER PADA IKLAN HONDA VARIO VERSI DANIEL MANANTA TERHADAP MINAT BELI HONDA VARIO DI KOTA YOGYAKARTA" Dari hasil penelitian ini ditemukan (1) Ada pengaruh kredibilitas celebrity endorser Daniel Mananta dalam produk Honda Vario terhadap minat beli di kota Yogyakarta. Hal ini dibuktikan dengan hasil pengujian hipotesis dengan nilai signifikansi sebesar 0,002. (2) Ada pengaruh kecocokan celebrity endorser Daniel Mananta dalam produk Honda Vario terhadap minat beli di kota Yogyakarta. Hal ini dibuktikan dengan hasil pengujian hipotesis dengan nilai signifikansi sebesar 0,000. (3) Ada pengaruh daya tarik celebrity endorser Daniel Mananta dalam produk Honda Vario terhadap minat beli di kota Yogyakarta. Hal ini dibuktikan dengan hasil pengujian hipotesis dengan nilai signifikansi sebesar 0,001. (4) Ada pengaruh kredibilitas, kecocokan, dan daya tarik celebrity endorser Daniel Mananta dalam produk Honda Vario terhadap minat beli di kota Yogyakarta secara simultan. Hal ini dibuktikan dengan hasil pengujian hipotesis secara simultan dengan nilai signifikansi sebesar 0,000

Bertitik tolak dari penelitian ini, rekomendasi yang diperkirakan dapat dijadikan bahan pertimbangan untuk penelitian selanjutnya terkait dengan minat beli yang disebabkan oleh celebrity endorser hendaknya melihat faktor-faktor yang mempengaruhi dan variabel mana yang cocok untuk diteliti dan kemudian penggalian data secara mendalam untuk data yang lebih konkrit dan akurat.

\section{Hipotesis}


H1: Ada pengaruh kredibilitas celebrity endorser secara parsial terhadap minat beli mie sedap di Daerah Istimewa Yogyakarta.

$\mathrm{H} 2$ : Ada pengaruh kecocokan celebrity endorser secara parsial terhadap minat beli mie sedap di Daerah Istimewa Yogyakarta

H3: Ada pengaruh daya tarik celebrity endorser secara parsial terhadap minat beli mie sedap di Daerah Istimewa Yogyakarta.

H4: Ada pengaruh serempak/simultan kredibilitas, kecocokan, dan daya tarik celebrity endorser terhadap minat beli mie sedap di Daerah Istimewa Yogyakarta.

\section{METODE PENELITIAN}

\section{Populasi dan Sampel}

Pada penelitian ini, yang menjadi target populasi adalah konsumen umum yang pernah melihat iklan mie sedap versi Syahrini melalui media televisi di Daerah Istimewa Yogyakarta. Populasi dalam penelitian ini tidak dapat dipastikan berapa jumlahnya (indefinite). Sampel dalam penelitian ini berjumlah 80 responden yang pernah melihat iklan Mie Sedap versi Syahrini ditelevisi. Teknik pengambilan sampel yaitu non probability sampling dengan metode purposive sampling dan incidental sampling.

\section{Definisi Operasional}

\section{Jenis Variabel}

Variabel bebas (Independent Variable) yaitu variabel prediktor, merupakan variabel yang dapat mempengaruhi perubahan dalam variabel terikat dan mempunyai hubungan yang positif dan negatif. Adapun variabel bebas dalam penelitian ini adalah adalah :

a. Kredibilitas $\left(\mathrm{X}_{1}\right)$

Kredibilitas adalah keahlian dan kepercayaan. Keahlian (expertise) mengacu pada pengetahuan, pengalaman, atau keterampilan yang dimiliki seorang pendukung yang berhubungan dengan topik iklannya. Kepercayaan (trustworthiness) mengacu pada kejujuran, integritas dan dapat dipercayai seorang sumber.

b. Kecocokan $\left(\mathrm{X}_{2}\right)$

Kesamaan atau kecocokan ini merupakan atribut yang penting karena penonton cenderung lebih menyukai seseorang yang sedang berbagi dengan karakteristik yang sama. Seorang selebriti yang yang sedang membintangi iklan produk tertentu sepertinya dianggap sosok yang terpercaya yang mempunyai kesamaan karakter dengan para penonton dalam hal gender, umur, etnis, dan kelas sosial.

\section{c. Daya Tarik $\left(\mathrm{X}_{3}\right)$}

Daya tarik bukan hanya berarti daya tarik fisik. Meskipun daya tarik bisa menjadi atribut yang sangat penting, tetapi meliputi sejumlah karakteristik yang dapat dilihat khalayak dalam diri pendukung. Sifat-sifat kepribadian, gaya hidup, keatlisan postur tubuh, keramahan, menyenangkan, fisik dan sebagainya.

2. Variabel terikat (Dependent Variable) atau disebut variabel kriteria, menjadi perhatian utama (sebagai faktor yang berlaku dalam pengamatan) dan sekaligus menjadi sasaran dalam penelitian. Variabel terikat dalam penelitian ini adalah Minat Beli

a. Minat beli (Y)

Minat Beli merupakan suatu proses yang mendorong seseorang untuk yakin dalam melakukan pembelian. Munculnya minat beli berasal dari pencarian informasi terkait pengetahuan, ketertarikan dan promosi.

\section{Uji Instrumen}

\section{Uji Validitas}

Uji validitas adalah ukuran yang menunjukkan sejauh manainstrumen pengukuran mampu mengukur apa yang 
ingin diukur (Sugiyono,2014). Uji validitas dalam penelitian ini menggunakan metode confirmatory factor analysis (CFA) atau analisis faktor, yaitu dengan cara melihat tabel component matrix. Jika dalam table component matrix terdapat dua kolom atau lebih maka terdapat pernyataan yang tidak valid dari kuesioner. Sehingga peneliti diwajibkan untuk mengeluarkan indikator yang memiliki Measures Of Sampling Adequacy (MSA) dibawah 0.50, jika nilai yang dibawah 0.50 sudah habis, maka yang dikeluarkan adalah yang memiliki MSA terkecil. Dengan cara ini pada akhirnya akan menghasilkan pernyataan yang valid apabila dalam table component matrix hanya terbentuk satu komponen saja (Adhilla, 2015).

\section{Uji Reliabilitas}

Realibilitas adalah alat untuk mengukur suatu kuisioner yang merupakan indikator dari variabel atau konstruk. Suatu kuisioner dikatakan handal atau reliabel jika jawaban seseorang terhadap pernyataan adalah konsisten atau stabil dari waktu ke waktu (Sugiyono, 2014), Realibilitas suatu konstruk dikatakan baik apabila memiliki nilai cronbach's alpha lebih besar dari 0,6 .

\section{Teknik Analisis Data}

1. Analisis Regresi Berganda

Analisis regresi linier berganda digunakan untuk mengetahui ada tidaknya pengaruh kredibiltas, kecocokan dan daya tarik terhadap minat beli. dengan kata lain analisis regresi linier berganda digunakan untuk menentukan suatu variabel terikat atau dependen, yang disebabkan oleh variabel bebas atau independen. $Y=a+\beta_{1} X_{1}+\beta_{2} X_{2}+\beta_{3} X_{3}+e$
Dimana :

Y = Minat beli

a $\quad=$ konstanta

$\mathrm{X}_{1} \quad=$ Kredibilitas

$\mathrm{X}_{2} \quad=$ Kecocokan

$\mathrm{X}_{3} \quad=$ Daya Tarik

$\beta=$ Koefisien regresi

e $\quad=$ Error

\section{Uji Hipotesis}

1. Uji Parsial (Uji T)

Uji t digunakan untuk mengetahui signifikansi pengaruh variabel independen secara individu terhadap variabel dependen untuk menyatakan menolak atau menerima hipotesis. Langkah-langkah Uji $\mathrm{t}$ sebagai berikut :

1. Perumusan hipotesis pertama

$\mathrm{H}_{0}$ : Tidak ada pengaruh kredibiltas terhadap minat beli konsumen.

$\mathrm{H}_{1}$ : Ada pengaruh kredibilitas terhadap minat beli konsumen.

2. Perumusan hipotesis kedua

$\mathrm{H}_{0}$ : Tidak ada pengaruh kecocokan terhadap minat beli konsumen.

$\mathrm{H}_{2}$ : Ada pengaruh kecocokan terhadap minat beli konsumen.

3. Perumusan hipotesis ketiga

$\mathrm{H}_{0}$ : Tidak ada pengaruh daya tarik terhadap minat beli konsumen.

$\mathrm{H}_{3}$ : Ada pengaruh daya tarik terhadap minat beli konsumen.

4. Penentuan nilai kritis

Jika nilai sign $>0,05$ maka, $\mathrm{H}_{0}$ diterima dan $\mathrm{H}_{\mathrm{a}}$ ditolak.

Jika nilai sign. $<0,05$ maka, $\mathrm{H}_{0}$ ditolak dan $\mathrm{H}_{\mathrm{a}}$ diterima.

\section{Uji Simultan (Uji F)}

Uji f atau disebut ANOVA (analysis of variance) merupakan salah satu uji komparatif yang digunakan untuk menguji perbedaan rata-rata data pada lebih dari dua kelompok atau secara simultan (Adhila, 2013).

a. Perumusan hipotesis H0 : Tidak ada pengaruh kredibilitas, kecocokan dan daya tarik terhadap minat beli konsumen. 
Ha : Terdapat pengaruh kredibilitas, kecocokan dan daya tarik terhadap minat beli konsumen.

b. Nilai kritis uji F dengan signifikansi (a) 0,05 .

Jika nilai sig $<0,05$ maka $\mathrm{Ha}$ diterima dan menolak $\mathrm{H} 0$

Jika nilai sig $>0,05$ maka $\mathrm{H} 0$ diterima dan menolak Ha

2. Uji Koefisien Determinasi

Dari hasil perhitungan akan diperoleh koefisien determinasi yang telah disesuaikan $\left(\mathrm{R}^{2}\right)$ atau $\mathrm{R}$ square sehingga akan diperoleh prosentase dari minat beli (Y) terhadap mie sedap dan dapat dijelaskan oleh variabel iklan sehingga variabel bebas yang dilakukan penuh mengenai atribut iklan melalui media televisi terhadap pembelian mie sedap yaitu: kredibiltas $\left(\mathrm{X}_{1}\right)$, kecocokan $\left(\mathrm{X}_{2}\right)$, daya tarik $\left(\mathrm{X}_{3}\right)$, yang diperoleh dari kondisi variabel terkait diterangkan oleh variabel bebas dan yang tidak diamati dianggap tetap. Apabila $\mathrm{R}^{2}$ sama dengan nol (0) berarti variabel independen tidak menjelaskan variabel dependen, sedangkan bila $\mathrm{R}^{2}$ sama dengan satu (1) berarti variabel independen dapat dijelaskan variabel dependen secara serempak.

\section{HASIL PENELITIAN DAN PEMBAHASAN}

\section{Hasil Analisis Responden}

Jumlah kuesioner yang disebar sebanyak 80 kuesioner dengan responden konsumen umum yang pernah melihat iklan Mie Sedap melalui media televisi di Daerah Istimewa Yogyakarta. Dengan data responden sebagai berikut:

\begin{tabular}{|l|l|l|l|l|}
\hline \multirow{2}{*}{$\begin{array}{l}\text { Respond } \\
\text { en }\end{array}$} & \multicolumn{4}{|c|}{ Kuesioner } \\
\cline { 2 - 5 } & $\begin{array}{l}\text { Diseb } \\
\text { ar }\end{array}$ & $\begin{array}{l}\text { Kemba } \\
\text { li }\end{array}$ & $\begin{array}{l}\text { Gugu } \\
\text { r }\end{array}$ & $\begin{array}{c}\text { Digunak } \\
\text { an }\end{array}$ \\
\hline Laki-laki & 46 & 46 & 0 & 46 \\
\hline Perempua & 34 & 34 & 0 & 34 \\
\hline
\end{tabular}

\begin{tabular}{|l|l|l|l|l|}
\hline $\mathrm{n}$ & & & & \\
\hline Total & 80 & 80 & 0 & 80 \\
\hline
\end{tabular}

\section{Hasil Penelitian}

1. Hasil Uji Validitas

\begin{tabular}{|c|c|c|c|c|c|}
\hline Indikator & $\begin{array}{c}\text { Kredibilitas } \\
\mathbf{X}_{1}\end{array}$ & $\begin{array}{c}\text { Kecocokan } \\
\mathbf{X}_{2}\end{array}$ & $\begin{array}{c}\text { Daya } \\
\text { Tarik } \mathbf{X}_{3}\end{array}$ & $\begin{array}{c}\text { Minat Beli } \\
\mathbf{Y}\end{array}$ & Keterangan \\
\hline X1.2 & 0,720 & & & & Valid \\
\hline X1.3 & 0,500 & & & & Valid \\
\hline X1.4 & 0,626 & & & & Valid \\
\hline X1.5 & 0,793 & & & & Valid \\
\hline X1.6 & 0,775 & & & & Valid \\
\hline X2.1 & & 0,872 & & & Valid \\
\hline X2.2 & & 0,897 & & & Valid \\
\hline X2.3 & & 0,791 & & & Valid \\
\hline X2.4 & & 0,376 & & & Valid \\
\hline X2.6 & & 0,867 & & & Valid \\
\hline X3.1 & & & 0,751 & & Valid \\
\hline X3.2 & & & 0,754 & & Valid \\
\hline X3.3 & & & 0,832 & & Valid \\
\hline X3.4 & & & 0,697 & & Valid \\
\hline Y1 & & & & 0,773 & Valid \\
\hline Y2 & & & & 0,778 & Valid \\
\hline Y3 & & & & 0,739 & Valid \\
\hline Y4 & & & & 0,642 & Valid \\
\hline Y5 & & & & 0,738 & Valid \\
\hline
\end{tabular}

Dalam pengujian Validitas kedua $\mathrm{X} 1.1, \quad \mathrm{X} 2.5, \quad \mathrm{Y} 6$ dihilangkan karena memiliki nilai MSA (Measure of Sampling Adequacy) paling kecil yaitu (X1.1 = $0,506),(\mathrm{X} 2.5=0,788)$ dan $(\mathrm{Y} 6=-0,070)$. Sehingga jika dilihat dari tabel 4.3 diatas bahwa semua indikator pernyataan mengelompok pada variabel penelitian masing-masing atau dalam tabel Component Matrix sudah terbentuk satu komponen saja. Yang berarti masingmasing indikator Valid dan hanya menjelaskan variabelnya.

2. Hasil Uji Reliabilitas

\begin{tabular}{|c|c|c|c|}
\hline Variabel & $\begin{array}{c}\text { cronbatch's } \\
\text { alpha }(\boldsymbol{\alpha})\end{array}$ & $\begin{array}{c}\text { cronbatch's } \\
\text { alpha } \\
\text { (konstruk) }\end{array}$ & Keputusan \\
\hline Kredibilitas & 0.707 & 0.60 & Reliabel \\
\hline Kecocokan & 0.858 & 0.60 & Reliabel \\
\hline Daxa Tarik & 0.749 & 0.60 & Reliabel \\
\hline Minat Beli & 0.674 & 0.60 & Reliabel \\
\hline
\end{tabular}

Berdasarkan hasil ringkasan $\mathrm{Uji}$ Reliabilitas pada tabel 4.3 maka dapat diketahui nilai Koefisien Cronbath alpha ( $\alpha$ ) pada masing-masing variabel $>0.60$ sehingga dapat disimpulkan bahwa semua 
pernyataan dalam penelitian ini Reliabel atau konsisten, sehingga dapat digunakan untuk penelitan selanjutnya.

3. Hasil Uji Regresi Linier Berganda

\begin{tabular}{|l|c|c|c|c|c|}
\hline \multirow{2}{*}{ Model } & \multicolumn{2}{|c|}{$\begin{array}{c}\text { Unstandardized } \\
\text { Coefficients }\end{array}$} & $\begin{array}{c}\text { Standardized } \\
\text { Coefficients }\end{array}$ & \multirow{2}{*}{} & \multirow{2}{*}{ Sig. } \\
\cline { 2 - 5 } & $\mathrm{B}$ & $\begin{array}{c}\text { Std. } \\
\text { Error }\end{array}$ & Beta & $\mathrm{t}$ & \\
\hline (constant) &,- 073 &, 457 & &, 161 &, 873 \\
\hline $\begin{array}{l}\text { Kredibilitas } \\
\text { X1 }\end{array}$ &, 394 &, 100 &, 365 & 3.957 &, 000 \\
\hline $\begin{array}{l}\text { Kecocokan } \\
\text { X2 }\end{array}$ &, 371 &, 087 &, 410 & 4,281 &, 000 \\
\hline $\begin{array}{l}\text { Daya Tarik } \\
\text { X3 }\end{array}$ &, 215 &, 088 &, 193 & 2,439 &, 017 \\
\hline
\end{tabular}

Berdasarkan hasil uji regresi linier berganda tabel 4.11 dapat diketahui persamaan regresi berganda sebagai berikut:

$$
\begin{aligned}
& Y=-0,073+0,394 X_{1}+0,371 X_{2}+0,215 X_{3} \\
& +\mathrm{e}
\end{aligned}
$$

Keterangan:

a. Nilai konstanta persamaan diatas sebesar -0,073. Angka tersebut menunjukkan tingkat minat beli konsumen bila tingkat kredibilitas, kecocokan dan daya tarik diabaikan.

b. Nilai koefisien beta pada variabel kredibilitas sebesar 0,394 yang artinya setiap penurunan variabel kredibilitas (X1) sebesar satu-satuan akan mengakibatkan perubahan minat beli konsumen sebesar 0,394. Sebaliknya jika terjadi kenaikan satu-satuan pada variabel kredibilitas akan menaikan minat beli konsumen sebesar 0,394 dengan asumsi-asumsi lain tetap.

c. Nilai koefisien beta pada variabel kecocokan sebesar 0,371 yang artinya setiap perubahan variabel kecocokan (X2) sebesar satu-satuan akan mengakibatkan perubahan keputusan minat beli sebesar 0,371. Sebaliknya jika penurunan satu-satuan pada variabel kecocokan akan menurunkan keputusan minat beli sebesar 0,371 dengan asumsi-asumsi lain tetap.

d. Nilai koefisien beta pada variabel daya tarik sebesar 0,215 yang artinya setiap perubahan variabel daya tarik (X3) sebesar satu-satuan akan mengakibatkan perubahan keputusan minat beli sebesar 0,215. Sebaliknya jika penurunan satu-satuan pada variabel daya tarik akan menurunkan keputusan minat beli sebesar 0,215 dengan asumsi-asumsi lain tetap.

Dari persamaan tersebut dapat dijelaskan bahwa koefisien beta variabel kredibilitas (X1) memiliki nilai positif, yang artinya jika variabel kredibilitas meningkat maka minat beli konsumen juga meningkat. Nilai koefisien beta variabel kecocokan (X2) memiliki nilai positif, yang artinya jika variabel kecocokan meningkat maka minat beli konsumen juga meningkat. Nilai koefisien beta daya tarik (X3) memiliki nilai positif, yang artinya jika variabel daya tarik meningkat, maka minat beli konsumen juga meningkat. Untuk mengetahui apakah hipotesis yang diajukan dalam penelitian ini diterima atau ditolak maka akan dilakukan pengujian hipotesis dengan menggunakan uji $\mathrm{t}$ dan uji F, hasil pengujian sebagai berikut:

\section{Hasil Uji Parsial (Uji T)}

\begin{tabular}{|c|c|}
\hline & Sig \\
\hline Constant &, 873 \\
\hline Kredibilitas &, 000 \\
\hline Kecocokan &, 000 \\
\hline Daya Tarik &, 017 \\
\hline
\end{tabular}

a. Kredibilitas (X1)

Berdasarkan tabel 4.12 hasil statistik uji t untuk variabel kredibilitas diketahui bahwa nilai signifikansi 0,000 . Hal ini menunjukkan bahwa angka probabilitas signifikansi variabel kredibilitas (X1) lebih kecil dari 0.05 yaitu $(0,000<0.05)$. Berdasarkan hasil tersebut dapat disimpulkan $\mathrm{H}_{\mathrm{a}}$ diterima dan $\mathrm{H}_{0}$ ditolak. Yang berarti ada pengaruh signifikan kredibilitas terhadap minat beli konsumen. b. Kecocokan (X2) 
Berdasarkan tabel 4.12 hasil statistik uji $\mathrm{t}$ untuk variabel kecocokan diketahui bahwa nilai signifikansi 0,000. Hal ini menunjukkan bahwa angka probabilitas signifikansi variabel kecocokan (X2) lebih kecil dari 0.05 yaitu $(0,000<0.05)$. Berdasarkan hasil tersebut dapat disimpulkan $\mathrm{H}_{\mathrm{a}}$ diterima dan $\mathrm{H}_{0}$ ditolak. Yang berarti ada pengaruh signifikan kecocokan terhadap minat beli konsumen. c. Daya Tarik (X3)

Berdasarkan tabel 4.12 hasil statistik uji t untuk daya tarik produk diketahui bahwa nilai signifikansi 0,017 . Hal ini menunjukkan bahwa angka probabilitas signifikansi variabel daya tarik (X3) lebih kecil dari 0.05 yaitu $(0,017<0.05)$. Berdasarkan hasil tersebut dapat disimpulkan $\mathrm{H}_{\mathrm{a}}$ diterima dan $\mathrm{H}_{0}$ ditolak. Yang berarti ada pengaruh signifikan daya tarik terhadap minat beli konsumen.

5. Hasil Uji Simultan (Uji F)

\begin{tabular}{|c|}
\hline Sig \\
\hline $0.000^{\circ}$ \\
\hline
\end{tabular}

Berdasarkan hasil uji $\mathrm{F}$ diperoleh nilai signifikansi 0,000 dimana nilai signifikansi lebih kecil dari 0,05 $(0,000<0,05)$. dengan demikian hipotesis yang menyatakan terdapat pengaruh positif dan signifikan antara kredibilitas, kecocokan, dan daya tarik secara bersamasama terhadap minat beli konsumen terbukti.

\section{Hasil Uji Koefisien Determinasi}

Hasil R-square pada penelitian ini diperoleh nilai R-square sebesar 0,567. Hal ini menunjukkan bahwa minat beli konsumen yang dipengaruhi kredibilitas, kecocokan dan daya tarik sebesar $56,7 \%$ sedangkan sisanya $43,3 \%$ dipengaruhi faktor lain yang tidak diteliti dalam penelitian ini.

\section{Pembahasan}

\section{Pengaruh kredibilitas terhadap minat beli produk mie sedap}

Ada pengaruh yang signifikan antara kredibilitas terhadap minat beli produk mie sedap. Hal ini ditunjukan dari nilai signifikansi 0,000 dimana nilain signifikansi lebih kecil dari 0,05 $(0,000<$ $0,05)$ dan koefisien regresi memiliki nilai positif 0,394. Maka dalam penelitian ini berhasil membuktikan hipotesis "ada pengaruh kredibilitas terhadap minat beli produk mie sedap" terbukti.

2. Pengaruh kecocokan terhadap minat beli produk mie sedap

Ada pengaruh yang signifikan antara kecocokan terhadap minat beli produk mie sedap. Hal ini ditunjukan dari nilai signifikansi 0,000 dimana nilai signifikansi lebih kecil dari 0,05 $(0,000<$ $0,05)$ dengan koefisien regresi memiliki nilai positif 0,371 . Maka dalam penelitian ini berhasil membuktikan bahwa hipotesis "ada pengaruh kecocokan terhadap minat beli produk mie sedap" terbukti.

3. Pengaruh daya tarik terhadap minat beli produk mie sedap

Ada pengaruh yang signifikan antara daya tarik terhadap minat beli produk mie sedap hal ini ditunjukan dari nilai signifikansi 0,017 dimana nilai signifikansi lebih kecil dari 0,05 $(0,017<$ $0,05)$ dengan koefisien regresi memiliki nilai positif 0,215 . Maka dalam penelitian ini berhasil membuktikan hipotesis "ada pengaruh daya tarik terhadap minat beli produk mie sedap" terbukti.

\section{KESIMPULAN DAN SARAN}

\section{Kesimpulan}

Berdasarkan hasil peneltian dan pembahasan pada bab sebelumnya, tentang pengaruh kredibilitas, kecocokan dan daya tarik terhadap minat beli produk mie sedap maka dapat ditarik kesimpulan sebagai berikut:

\section{Kredibilitas (X1)}

Ada pengaruh yang signifikan antara kredibilitas terhadap minat 
beli konsumen mie sedap. Hal ini ditunjukan dari nilai $t_{\text {hitung }} 3,957$ dengan nilai signifikansi 0,000 dimana nilai signifikansi lebih kecil dari $0,05(0,000<0,05)$.

2. Kecocokan (X2)

Ada pengaruh yang signifikan antara kecocokan terhadap minat beli konsumen mie sedap. Hal ini ditunjukan dari nilai $t_{\text {hitumg }} 4,281$ dengan nilai signifikansi 0,000 dimana nilai signifikansi lebih kecil dari $0,05(0,000<0,05)$.

3. Daya Tarik (X3)

Ada pengaruh yang signifikan antara daya tarik terhadap minat beli konsumen mie sedap hal ini ditunjukan dari nilai $t_{\text {hitung }} 2,439$ dengan nilai signifikansi 0,017 dimana nilai signifikansi lebih kecil dari $0,05(0,017<0,05)$.

4. Terdapat pengaruh positif dan signifikan antara kredibilitas, kecocokan dan daya tarik secara bersama-sama terhadap minat beli konsumen mie sedap hal ini dibuktikan dengan nilai signifikansi 0,000 lebih kecil dari $0,05(0,000<$ $0,05)$.

5. Uji koefisien determinasi R-square diperoleh nilai sebesar 0,567 hal ini menunjukkan bahwa keputusan pembelian konsumen yang dipengaruhi iklan, harga, kualitas produk, sebesar $56,7 \%$ sedangkan sisanya $43,3 \%$ dipengaruhi faktor lain yang tidak diteliti dalam penelitian ini.

\section{Saran}

Berdasarkan hasil penelitian, pembahasan dan kesimpulan yang diperoleh, maka saran yang diberikan sebagai berikut:

1. Bagi Perusahaan

Berdasarkan penelitian yang telah dilakukan tentang "Pengaruh Penggunaan Celebrity Endorser Syahrini Terhadap Minat Beli Mie Sedap Di Daerah Istimewa
Yogyakarta”, maka saran yang ingin penulis sampaikan adalah Wingsfood sebagai produsen harus melakukan inovasi-inovasi dan ideide baru yang terdapat di produk Mie sedap guna mempertahankan persepsi penonton yang mempunyai nilai positif ke Mie sedap dan juga pengaruh Syahrini sebagai selebriti pendukung yang mempunyai nilai positif dalam pembentukan minat beli Produk Mie sedap harus dipertahankan.

2. Penelitian selanjutnya

Bagi penelitian selanjutnya yang menggunakan objek atau tema yang sama dapat menambahkan variabel lain yang dapat mempengaruhi minat beli konsumen, seperti harga, kualitas produk dan promosi. Untuk penelitian selanjutnya pengisian kuisioner sebaiknya dipandu secara langsung oleh peneliti sehingga didapatkan data penelitian yang baik dan maksimal.

\section{DAFTAR PUSTAKA}

Adhila, Fitroh, Dyah Fitriani, dan Deny Ismanto. 2013. Modul Praktikum Statistik 2. Yogyakarta: Universitas Ahmad Dahlan.

Adhilla, Fitroh. 2015. Modul praktikum analisis multivariate 1. Yogyakarta: Fakultas Ekonomi Universitas Ahmad Dahlan.

Basu Swastha.(2009). Manajemen Penjualan. Yogyakarta: BPFE.

Cangara, Hafied H, 2006, Pengantar Ilmu Komunikasi, PT. Raja Grafindo. Persada, J

Daryanto, 2011, Sari Kuliah Manajemen Pemasaran, Bandung: PT Sarana. Tutorial Nurani Sejahtera.

Fandy Tjiptono, 2007, Strategi Pemasaran. Edisi ke dua, penerbit Andi,. Yogya 
Kotler, Philip dan Kevin Lane Keller, 2008. Manajemen Pemasaran, Jilid 1,. Penerbit Erlangga. Jakarta

Kotler, Philip, dan Kevin Lane Keller. 2009. Manajemen Pemasaran Jilid 1, edisi Ke Tiga Belas.

Kotler, Philip, dan Kevin Lane Keller. 2009. Manajemen Pemasaran Jilid 2, edisi Ketiga.

Machfoedz, Mahmud. 2010. Komunikasi Pemasaran Modern. Yogyakarta : Cakra. Ilmu.

Mustafa, Zainal EQ. 2009 Mengurai Variabel Hingga Instrumentasi, Yogyakarta: Graha Ilmu.

Oentoro, Deliyanti. (2012). Manajemen Pemasaran Modern, Yogyakarta

Rofiq, Abdur, 2016. "Pengaruh Penggunaan Celebrity Endorser Daniel Mananta Terhadap Minat Beli Honda Vario di KotaYogyakarta." Skripsi Yogyakarta: Fakultas Ekonomi Universitas Ahmad Dahlan.

Raviany, Arma Hedita Sepala, 2011. "Analisis Pengaruh Efektivitas Iklan Pesaing dan Perilaku Mencari Variasi Terhadap Perilaku Perpindahan Merek pada Konsumen Tehbotol Sosro" Skripsi Semarang: Fakultas Ekonomi UNDIP.

Rosiana , Tri Handayani. 2012. Bauran Pemasaran .Edisi 12 jilid 2. Jakarta: Erlangga.

Shimp, A Terence, 2003. Periklanan Promosi dan Aspek Tambahan. Komunikasi Pemasaran Terpadu Jilid 1 (Edisi5), Jakarta, Erlangga

Simamora. (2001). Memenangkan Pasar dengan Pemasaran Efektif dan. Profitabel. Edisi pertama. Jakarta: PT. Gramedia Pustaka .
Sugiyono. 2014. Metode Penelitian Kuantitatif, Kualitatif, dan Kombinasi (Mixed. Methods). Bandung :

Sulaksana, Uyung. 2003. Integrated Marketing Communications. Yogyakarta

Tjiptono, Fandy, 2008, Strategi Pemasaran, Edisi 3, ANDI: Yogyakarta.

Umar, Husein, 2002. Evaluasi Kinerja Perusahaan, PT Gramedia Pustaka Utama,. Jakarta

Yusnidar, dkk. 2014. Pengaruh Kepercayaan Dan Persepsi Resiko Terhadap Minat Beli Dan Keputusan Pembelian Produk Fashion Secara Online Di Kota Pekanbaru. Jurnal Sosial Ekonomi Pembangunan. Tahun IV No.12, Juli : 311-329 